izv. prof. dr. sc. Ljubica Milanović Glavan¹

Nikolina Filić, mag. oec.

\title{
RAZVOJ PAMETNIH GRADOVA U REPUBLICI HRVATSKOJ
}

Pregledni rad / Review paper

UDK / UDC: 711.4:004(497.5)

DOI: $10.51650 /$ ezrvs. $15.3-4.8$

Primljeno / Received: 21/10/2021

Prihvaćeno / Accepted: 9/12/2021

\begin{abstract}
Pametan grad trebao bi osigurati urbano okruženje koje stanovnicima pruža visoku kvalitetu života, a istovremeno generira gospodarski rast.. Pametni gradovi danas nisu samo globalni trend, nego postaju potreba. Uspjeh pametnog grada zahtijeva suradnju s građanskim vlastima obzirom da je koordinacija između različitih razina vlasti često najveći izazov za pametne gradove. Budućnost gradova leži u spajanju novih tehnologija sa postojećom infrastrukturom radi rješavanja opipljivih, hitnih pitanja kao što su održivost okoliša i gospodarske mogućnosti. Uspješni pametni gradovi izgradit će snažnu, fleksibilnu, digitalnu infrastrukturu koja integrira novu tehnologiju u postojeću strukturu. U ovome se radu istražuje koncept pametnoga grada i njegovi elementi, kao i trendovi u primjeni koncepta pametnih gradova na području Republike Hrvatske. Rezultati istraživanja pokazuju da je primjena koncepta pametnih gradova prepoznata te su se pojedini hrvatski gradovi već uključili u proces implementacije određenih komponenti pametnih gradova.
\end{abstract}

Ključne riječi: pametni gradovi, EU fondovi, Zagreb, Rijeka.

\section{Uvod}

Razvoj tehnologije i ubrzani procesi globalizacije doveli su do promjene načina razvoja gradova. Pri razvoju gradova danas glavni cilj jest učiniti ih samostalnima, odnosno samoodrživima. Stoga se u zadnjih par godina sve više spominje koncept pametnog grada. Pametni gradovi se opisuju se kao gradovi koji pružaju temeljnu infrastrukturu i pristojnu kvalitetu života svojim građanima, čisto i održivo okruženje te primjenu pametnih rješenja. Prema Europskoj Komisiji pametni grad je mjesto na kojem se tradicionalne mreže i usluge čine učinkovitijim pomoću digitalnih i telekomunikacijskih tehnologija za dobrobit njegovih stanovnika i poduzeća. Gradovi i njihova infrastruktura složeni su kompleksi, koji svakodnevno trebaju ići ukorak s vremenom i jednakom brzinom napredovati i rasti kako bi zadovoljili potrebe građana. Neki gradovi u tome uspijevaju bolje, a neki lošije. Kakav god se koncept

${ }^{1}$ Ekonomski fakultet Sveučilišta u Zagrebu, e-mail: ljmilanovic@efzg.hr 
pametnoga grada koristi, uvijek je usmjeren na pametnija i održivija rješenja u svrhu poboljšanja gospodarskih prilika i kvalitete života.

U Hrvatskoj je sve više gradova započelo tranziciju iz običnih urbanih središta u urbana središta koja koriste pametna rješenja u svakodnevnom životu. Samom tom tranzicijom javlja se i problem financiranja s jedne strane, ali i potencijala koji razvoj takvih središta nudi. Cilj ovoga rada jest analizirati razvoj pametnih gradova u Republici Hrvatskoj. U radu će se definirati koncept pametnih gradova i njihovi elementi te će se prikazati studije slučaja pametnih gradova Zagreba i Rijeke.

Rad je podijeljen na pet poglavlja. Uvodno poglavlje prikazuje cilj i strukturu rada. U drugom poglavlju prikazano je pojmovno određenje te značajke pametnih gradova. Treće poglavlhje definira glavne elemente pametnih gradova. $U$ četvrtom poglavlju prikazana je analiza pametnih gradova u Republici Hrvatskoj. Zadnje poglavlje nudi zaključna razmatranja.

\section{Pojmovno određenje i značajke pametnih gradova}

Pojam pametnog grada (eng. smart city) se u literaturi često navodi kao sposobnost grada da na efikasan način, u što skorijem vremenu udovolji raznim potrebama građana. Sveobuhvatna misija pametnog grada je optimizirati gradske funkcije i potaknuti gospodarski rast, istovremeno poboljšavajući kvalitetu života svojih građana pomoću pametne tehnologije i analize podataka. Pametni grad koristi informacijske i komunikacijske tehnologije za povećanje operativne učinkovitosti, razmjenu informacija s javnošću i poboljšanje kvalitete usluga i dobrobiti građana (Shea i Burns, 2020). Vrijednost pametnog grada leži u načinu korištenja ove tehnologije, a ne samo u tome koliko je tehnologije na raspolaganju. Ključne karakteristike pametnih gradova su sljedeće: infrastruktura koja se temelji na tehnologiji, inicijative za zaštitu okoliša, učinkovit i vrlo funkcionalan javni prijevoz, samopouzdani i progresivni gradski planovi, ljudi koji mogu živjeti i raditi unutar grada, koristeći njegove resurse.

Uspjeh pametnog grada ovisi o njegovoj sposobnosti da uspostavi snažan odnos između vlade - uključujući njezinu birokraciju i propise - i privatnog sektora. Taj je odnos nužan jer se većina posla koji se radi na stvaranju i održavanju digitalnog okruženja na temelju podataka odvija izvan vlade.. Pametni gradovi koriste kombinaciju uređaja interneta stvari (eng. Internet of Things, lot), softverskih rješenja, korisničkog sučeljai komunikacijskih mreža. Međutim, oni se prije svega oslanjaju na loT. IoT je mreža povezanih uređaja - poput vozila, senzora ili kućanskih aparata - koji mogu komunicirati i razmjenjivati podatke. Podaci koje prikupljaju i isporučuju loT senzori i uređaji pohranjuju se u oblaku ili na poslužiteljima. Povezivanje ovih uređaja i upotreba analitike podataka olakšava konvergenciju fizičkih i digitalnih gradskih elemenata, poboljšavajući tako učinkovitost javnog i privatnog sektora, omogućujući ekonomske koristi i poboljšavajući živote građana (Prša, 2020).

$54 \%$ svjetske populacije živi u gradovima, a očekuje se da će se to povećati na $66 \%$ do 2050., dodajući daljnjih 2,5 milijardi ljudi gradskom stanovništvu tijekom sljedeća 3 desetljeća. S ovim očekivanim rastom stanovništva javlja se potreba upravljanja ekološkom, društvenom i ekonomskom održivošću resursa (Mohanty, 2016). Pametni gradovi omogućuju građanima i tijelima lokalne uprave da rade zajedno na pokretanju inicijativa i koriste pametne tehnologije za upravljanje imovinom i resursima u rastućem urbanom okruženju. 
Pametan grad trebao bi osigurati urbano okruženje koje stanovnicima pruža visoku kvalitetu života, a istovremeno generira gospodarski rast. To znači pružanje paketa združenih usluga građanima uz smanjene troškove infrastrukture. To postaje sve važnije u svjetlu budućeg porasta stanovništva u urbanim područjima, gdje će biti potrebno učinkovitije korištenje infrastrukture i imovine. Usluge i aplikacije pametnih gradova omogućit će ta poboljšanja koja će dovesti do veće kvalitete života građana.

\section{Najvažniji elementi pametnih gradova}

Pametni gradovi nisu samo globalni trend nego postaju potreba današnjice. Kako bi postali pametni, gradovi moraju imati najmanje 5 od 6 navedenih elemenata: pametno upravljanje, pametno društvo, pametna briga za ljude i okoliš, pametna infrastruktura i mobilnost, pametna tehnologija i energija te pametne građevine (Cifaldi i Serban, 2018).

\subsection{Pametno upravljanje}

Meijer i Bolivar (2016) identificirali su četiri tipična koncepta pametnog upravljanja gradom: 1. vlada pametnog grada, 2. pametno donošenje odluka, 3. pametna administracija i 4. pametna urbana suradnja. Meijer i Bolivar (2016) ističu da prvi tip koncepta sugerira kako nema potrebe za promjenama upravljačkih struktura i procesa, drugi tip naglašava potrebu za procesom pametnog donošenja odluka i implementacijom tih odluka, treći tip odnosi se na kreiranje pametne administracije, dok četvrti tip podrazumijeva pametnu urbanu suradnju među različitim dionicima grada. Svako uvođenje novih tehnoloških rješenja ne samo u sklopu gradskih administracija već i u sklopu šire lokalne zajednice zahtijeva jako vodstvo, jasnu ideju, viziju, znanje, političku volju za provođenje određene promjene. Postati pametan grad, odnosno usvojiti koncept pametnoga grada nije moguće bez pametnog upravljanja. Uspjeh razvoja pametnoga grada više je od slogana na lokalnim političkim izborima. To je opredjeljenje i strategija budućeg razvoja nekoga grada. Iz tog su razloga opredijeljenost, karizmatičnost, jasna vizija, jasni ciljevi i odlučnost u provedbi promjena osnovne postavke pametnog upravljanja gradom. Dobro i pametno upravljanje rezultirat će dobrom primjenom i dugoročnim koristima za cijelu lokalnu zajednicu. Upravo se stoga nameće zaključak kako se pametno upravljanje temelji na pametnoj administraciji, uključuje digitalni način prikupljanja podataka te donošenje inovativnih rješenja, uz inovativne načine suradnje (Paliaga i Oliva, 2018).

\subsection{Pametno društvo}

Pametno društvo je skup sustava koji izražavaju sporazumno uspostavljen skup vrijednosti. To je društvo u kojem čelnici i građani donose odluke temeljene na podacima koje omogućuju stalno poboljšanje rezultata u ekonomskom prosperitetu, društvenoj dobrobiti, održivosti okoliša i dobrom upravljanju. Pametno društvo uključuje sustav nagrađivanja ili poticaja koji izaziva društveno poželjna i ekološki regenerirana ponašanja bez prisile ili kazne (Haupt, 2017). 


\subsection{Pametna briga za ljude i okoliš}

Pametna okruženja imaju potencijal dopustiti korisnicima da se angažiraju i neometano komuniciraju sa svojim neposrednim okruženjem. To je omogućeno uvođenjem inteligentnih tehnologija, zajedno sa softverskim uslugama. Očigledno je da je tehnološki napredak omogućio novo doba i za tehnologiju i za računalnu obradu kako bi se olakšao vid pametnih okruženja. lako postoje brojni izazovi u njihovom uvođenju, brojni programi velikih razmjera nastoje unaprijediti njihovo usvajanje (Wolter i Kirsch, 2017).

\subsection{Pametna infrastruktura i mobilnost}

Od početka urbanizacije mobilnost je ključno pitanje i važan pokretač rasta i napretka. U prošlosti je mobilnost mogla predstavljati slobodu ljudi da se kreću koristeći nova prijevozna sredstva u rastućim gradovima. No, u današnje vrijeme povezivanje prometa i komunikacije postaje sve važnije kako se prometna infrastruktura gura do krajnjih granica, raste potražnja za alternativnim prijevoznim sredstvima i rutama te raste pritisak za optimizacijom postojećih sustava. Inteligentno planiranje prometa, širenje javnog prijevoza i poboljšana međusobna povezanost svih sudionika u prometu u komunikacijskoj infrastrukturi na cijelom gradu obuhvaćaju karakteristike mobilnosti pametnog grada. Manje gužve u prometu u središtu grada i razvoj sustava javnog prijevoza s pretežno nultim emisijama u konačnici će imati pozitivan utjecaj na okoliš i kvalitetu života u pametnim gradovima (Fraunhofer, 2021).

Danas mobilnost nije samo pitanje slobodnog kretanja unutar grada i sigurnosti da će pošiljke stići na odredište. Mobilnost danas također znači da pametni grad neovisno prati tijek prometa i fleksibilno reagira na probleme. Osim toga, mobilnost se može prilagoditi novom komunikacijskom infrastrukturom. Na primjer, podaci o pristupačnosti u gradu i za dobrobit svih dostupni su svima, dijeljeni i stalno se ažuriraju. Time se stvara gradska otvorena mreža mobilnosti kroz stalnu razmjenu između svih uključenih strana radi maksimalne učinkovitosti.

\subsection{Pametna tehnologija i energija}

Pametna tehnologija naziv je za uređaje spojene na internet koji mogu prikupljati i prenositi podatke na središnje pohranjeno čvorište. Obično dolazi u obliku senzora i prijemnika i može pokazati koliko se energije troši u određenim područjima zgrade ili određenim strojevima (Fraunhofer, 2021).

Uloga pametnih tehnologija može postati vrlo važna i korisna za rješavanje glavnih problema stanovništva danas i pružiti temelje za održivu budućnost. Pametan pristup prilika je za integraciju znanja, neophodan za rješavanje ključnih problema suvremenih društava. Danas je glavni izazov smanjiti učinke globalnog zatopljenja i osigurati uravnotežen gospodarski razvoj društva. Bliska suradnja svih uključenih inženjerskih zanimanja obvezna je za postizanje interdisciplinarne sinergije i može premostiti izazovne inženjerske zadatke. Intenzivni istraživački napori trebali bi biti usmjereni prema uravnoteženom korištenju resursa, učinkovitim tehnologijama pretvorbe energije, integraciji sustava obnovljivih izvora energije, učinkovitim pristupima koji omogućuju okvir kružnog gospodarstva, učinkovitu integraciju procesa, kao i drugim pitanjima važnim za stanovništvo (Nižetić i sur., 2018). 


\subsection{Pametne građevine}

Pametna zgrada je svaka struktura koja koristi automatizirane procese za automatsku kontrolu rada zgrade, uključujući grijanje, ventilaciju, klimatizaciju, rasvjetu, sigurnosne i druge sustave (Nižetić i sur., 2019). Pametna zgrada koristi senzore i mikročipove za prikupljanje podataka i upravljanje njima u skladu s poslovnim funkcijama i uslugama. Ova infrastruktura pomaže vlasnicima, operaterima i upraviteljima objekata da poboljšaju pouzdanost imovine i performanse, što smanjuje potrošnju energije, optimizira način korištenja prostora i minimizira utjecaj zgrada na okoliš. Pametne zgrade su u biti živi organizmi povezani u mrežu s inteligentnim i prilagodljivim softverom.

\section{Pametni gradovi u Republici Hrvatskoj}

Škrlec (2017) navodi da je, prema nekim istraživanjima, Hrvatska relativno konzervativno društvo kada je riječ o usvajanju novih tehnoloških ideja. Međutim, iako u ovom vidu zaostaje za nizom urbanih područja Europske unije, sitnim korakom ipak napreduje. Od 128 hrvatskih gradova, njih više od 40 razvija koncept pametnih gradova te primjenjuje pametna rješenja koja omogućuju kvalitetniji život u gradu. Prema provedenom istraživanju od strane Fakulteta za prometne znanosti u Zagrebu, većina ispitanih hrvatskih gradova sudjeluje u nekim pojedinačnim projektima na temu pametnih gradova, e-upravljanja, smart city ili sličnog nazivlja, te su izjavili da planiraju izdvojiti određena financijska sredstva za provođenje koncepta pametnog grada (51,7\%). Među ispitanim hrvatskim gradovima, njih 32\% uključilo se u provedbu koncepta pametnog grada, a 64\% ih planira primijeniti (Paliaga i Oliva, 2018). Tri su bitna segmenta pametne mobilnosti: inteligentno korištenje informacijsko-komunikacijske tehnologije $(86,2 \%)$, pametan javni gradski prijevoz $(65,5 \%)$ i pametan parking $(58,6 \%)$. Implementirano (u primjeni): kontrola kvalitete zraka (33\%), kontrola i nadzor prometa (22\%), pametni parking (11\%). Također, istraživanje je indikativno otkrilo da se unutar gradova planira implementirati u budućnosti inteligentno korištenje informacijsko-komunikacijskim tehnologijama $(60,7 \%)$, pametnim parkiranjem (50\%), kontrolom i nadzorom prometa $(39,3 \%)$ te pametnim javnim gradskim prijevozom (32,1\%). Čakovec je tako, na primjer, prvi grad u Hrvatskoj koji će se moći pohvaliti pametnom rasvjetom (800.000 kn iz EU fondova), a Pula je još 2008. godine uvela u svoje poslovanje e-upravu, dok je Grad Zagreb proveo energetsku obnovu društvenih objekata te nekoliko projekata koji se tiču održivog prijevoza (Škrlec, 2017). Dubrovnik je primjer pokušaja optimizacije upravljanja odvozom otpada, posebno u vrijeme turističke sezone, koja, prema navodima Škrleca (2017), može olakšati ne samo izvršavanje funkcija komunalnih poduzeća već i život svih građana, uz pretpostavku da se učinkovito implementira i primjenjuje. Rovinj je prepoznao važnost komunikacije i interakcije sa svojim građanima pa je tako uveo koncept SMART Rovinj koji omogućuje u realnom vremenu niz komunalnih intervencija i interakcija, što rezultira bolje upravljanim i čišćim gradom (Paliaga i Oliva, 2018).

Hrvatska ima Nacionalnu razvojnu strategiju do 2030. godine, strateški dokument u kojem je posebno istaknut razvoj pametnih gradova i otoka, a Europski fond za regionalni razvoje od 2020. odvaja 6\%, umjesto dosadašnjih 5\% (https://ec.europa.eu/croatia/smart_city_in_Croatia_hr). Hrvatski gradovi trebali bi više ulagati u unaprjeđenje infrastrukture i moderna tehnološka rješenja. Upravo zato već petu godinu zaredom organizira se polugodišnji projekt 
"Pametni gradovi - gradovi budućnosti". Gradovi se natječu u nekoj od četiri kategorija: pametna energetika/okoliš, pametn promet (infrastruktura), pametna uprava i pametni život .

U nastavku će bit analizirana Rijeka kao pametni grad te Zagreb kao pametni grad.

\subsection{Rijeka kao pametni grad}

U sklopu dvogodišnjeg projekta Europske komisije "Intelligent Cities Challenge", kojem je prethodio projekt "Digital Cities Challenge", Rijeka je izabrana za jedan od 10 gradova-mentora koji će svojim rješenjima i iskustvom pomoći drugim gradovima u transformaciji prema pametnom gradu. Rijeka je ulogu grada-mentora dobila temeljem Strategije razvoja grada, Strateškog plana Rijeka pametni grad i Strategije digitalne transformacije. U proteklom je periodu Grad Rijeka znatno unaprijedio administrativne postupke i stupanj njihove učinkovitosti te dostupnost servisnih informacija na mrežnim stranicama Grada. Iskorak je učinjen i u stupnju objedinjenih servisa za plaćanje u gradu, otvorenom proračunu i participaciji građana u odlučivanju. Portal elektroničkih usluga http://gov.rijeka.hr nudi čitav niz usluga, a na njemu je registrirano preko 7.000 korisnika (Mrvoš. 2021).

Pametni gradovi su svjetski trend, a današnji vrlo brzi razvoj tehnologije omogućuje da se pametna rješenja za gradove trenutno mogu implementirati u urbane sredine. Sve veći promet u gradovima zahtijeva pametno upravljanje prometom. Treba unaprijediti protok prometa, što znači ne samo uštedu vremena već i čuvanje okoliša. Projekt "Jačanje gradskog prijevoza" u gradu Rijeci vrijedan je 81 milijuna kuna, dok EU putem bespovratnih sredstava financira čak 54 milijuna kuna. Jačanje gradskog prijevoza provest će se modernizacijom voznog parka, uvođenjem informativnih displeja na autobusnim stajalištima i uvođenjem pametnih semafora. Ciljevi projekta su: unaprjeđenje kapaciteta kroz povećanje brzine putovanja i smanjenja operativnih troškova, unaprjeđenje pouzdanosti i sigurnosti prometa, povećanje dostupnosti informacija za putnike, smanjenje razine štetnih plinova i zagađenja zraka.

Primjenom inteligentnih prometnih sustava nove generacije, Rijeka u budućnosti može postići još bolje rezultate u razvoju održive mobilnosti na području grada. Žele proširiti obuhvat područja opremljenog pametnim semaforima i brojačima prometa te razviti sustav za obradu podataka prikupljenih putem senzora u cilju upravljanja prometom u realnom vremenu. Veliki potencijal se vidi i u uvođenju pametnih sustava parkiranja u naseljima koji uključuju izgradnju inovativne infrastrukture uz informacijske sustave koji daju precizne podatke o slobodnim parkirnim mjestima.

\subsection{Zagreb kao pametni grad}

Grad Zagreb planira uz pomoć sredstava iz EU fondova te financiranjem iz Europske Investicijske banke ostvariti ciljeve koje su postavili u veljači 2019 godine u strateškom dokumentu "Okvirna strategija pametnog grada Zagreba - Zagreb Smart City". Navedena Strategija daje smjernice za primjenu inovativnih načina korištenja resursa i novih tehnologija, bolju koordinaciju gradske uprave kao i aktivno uključivanje građana u razvoj grada. U cilju realizacije vizije pametnog grada, Grad Zagreb se u svojoj Strategiji fokusirao na šest glavnih područja: digitalnu infrastrukturu, učinkovitu, transparentnu i pametnu gradsku upravu,pametno upravljanje energijom i komunalnim uslugama, obrazovanje, gospodarstvo i održivu urbanu mobilnost (Jezidžić, 2020). 
Digitalna revolucija se sve više ubrzava i više nije pitanje koju uslugu koristiti nego koju ponudu odabrati jer od tog odabira ovisi efikasnost rješenja i usluga. Novo digitalno rješenje je Zagreb City Hub na kojem će kroz različite digitalne nadzorne ploče biti dostupne sve informacije o digitalnoj infrastrukturi, javnoj upravi, aktivnom uključenju građana, upravljanju energijom i komunalnim uslugama, obrazovanju, gospodarstvu i poduzetništvu, urbanoj mobilnosti i drugim sferama upravljanja gradom. Platforma je namijenjena građanima, ali i obrtnicima te poduzetnicima, a trebala bi biti realizirana i objavljena na mrežnim stranicama Grada Zagreba do kraja godine. Digitalnom demokracijom, građani će preko platforme komunicirati o ključnim odlukama i biti uključeni u donošenje strateških odluka (Filić, 2021).

Transformacija Grada Zagreba u pametni Grad Zagreb utjecat će na tehnološke inovacije, pametan promet, energetsku učinkovitost, jačanje zajedničke suradnje gradske uprave i građana u provedbi zacrtanih mjera te u konačnici poboljšanje životnog standarda građana.

\section{Zaključak}

U 21. stoljeću sve više ljudi dolazi živjeti u urbanim naseljima. Povećanjem broja stanovnika u gradovima javljaju se različiti problemi, od povećanja gužve u prometu pa sve do zagađenja okoliša. Kako bi se navedeni problemi riješili sve više gradova okreće se k tehnoloških i digitalnim rješenjima te integracijom informatičkih i komunikacijskih tehnologija ti gradovi postaju pametni gradovi.

Republici Hrvatskoj je kroz Europske strukturne i investicijske fondove dozvoljeno sufinanciranje razvoja pametnih rješenja, a na nacionalnoj razini je donešena «Nacionalna razvojna strategija» u kojoj je strateški cilj razvoj pametnih gradova. Potaknuti time pojedini hrvatski gradovi već su se uključili u proces implementacije određenih komponenti pametnih gradova ili već primjenjuju tehnološka rješenja (Čakovec, Pula, Zagreb, Dubrovnik, Rovinj).

\section{LITERATURA}

1. Cifaldi, G. \& Serban, I. (2018), Between a Smart City and Smart Society, Intelligent Human Systems Integration, 714.-719.

2. EC Europa, https://ec.europa.eu/info/eu-regional-and-urban-development/topics/citiesand-urban-development/city-initiatives/smart-cities_en (pristupljeno 15.08.2021.).

3. Filić, N. (2021), Razvoj pametnih gradova, Završni rad, Ekonomski fakultet Zagreb.

4. Fraunhofer, https://www.fokus.fraunhofer.de/en/fokus/smart_cities_lab/topics/mobility (pristupljeno 15.08.2021.)

5. Haupt, M. (2017), What is a Smart Society? Toward the transcendent model society of 2030, Society 4.0., dostupno na: https://medium.com/project-2030/what-is-a-smartsociety-92e4a256e852 (pristupljeno 06.08.2021.) .

6. Jezidžić, A. (2020), Potencijal korištenja EU fondova za razvojpametnih gradova u RH, Završni rad, Ekonomski fakultet Split.

7. Meijer, A., Bolivar, M. P. R. (2016), Governing the smart city: a review of the literature on smart urban governance, International Review of Administrative Sciences, 82(2), 392.-408. 
8. Mohanty, S.P. (2016), Everything You Wanted to Know About Smart Cities, IEEE Consumer Electronics Magazine, 5 (3.), 60.-70.

9. Mrvoš, V. (2021), Rijeka kao najPametniji grad u Hrvatskoj želi biti još pametniji, dostupno na: https://www.novilist.hr/ostalo/promo/rijeka-kao-najpametniji-grad-u-hrvatskoj-zeli-biti-jospametniji/ (pristupljeno 17.09.2021.)

10. Nižetić, S., et.al. (2019), Smart technologies for promotion of energy efficiency, utilization of sustainable resources and waste management, Journal of Cleaner Production, 231(10), 565.-591.

11. Paliaga, M., Oliva, E. (2018), Trendovi u primjeni koncepta pametnih gradova, Ekonomska misao i praksa, 2, 565.-583.

12. Prša, M. (2020), Ekonomija obnovljivih izvora energije u kontekstu pametnog grada, Završni rad, Ekonomski fakultet Split.

13. Shea, S., Burns, E. (2020), Smart City", dostupno na: https://internetofthingsagenda.techtarget.com/definition/smart-city (pristupljeno 1.07.2021.).

14. Škrlec, D. (2017), Pametni gradovi -budućnost ili stvarnost?, dostupno na: https://www. davor-skrlec.eu/pametni-gradovi-buducnost-ili-stvarnost/ (pristupljeno 6. 6.2021.).

15. Wolter, D., Kirsch, A. (2017), Smart Environments: What is it and Why Should We Care?, KI - Künstliche Intelligenz, Springer Nature, 31 (3), 231-237

\title{
Summary
}

\section{DEVELOPMENT OF SMART CITIES IN CROATIA}

\begin{abstract}
A smart city should provide an urban environment that provides residents with a high quality of life while generating economic growth. Smart cities are not just a global trend, it is not some modern technological revolution that everyone dreams of, in fact, smart cities are a necessity and must be implemented as soon as possible. The success of a smart city requires collaboration with civilian authorities, such as local or federal privacy commissioners, as coordination between different levels of government is often the biggest challenge for smart cities. The future of cities lies in merging new technologies with existing infrastructure to address tangible, urgent issues such as environmental sustainability and economic opportunities. Successful smart cities will build a strong, flexible, digital infrastructure that integrates new technology into the existing structure. The paper explores the smart city concept and its elements, along with the trends in its application in Croatia. Research results show that the application of the smart city concept has been recognized and some Croatian cities have already been involved in the process of implementing certain smart city components.
\end{abstract}

Keywords: smart cities, EU funds, Zagreb, Rijeka. 